\title{
OPTIMATION OF PLATELET RICH PLASMA PRODUCTION PROTOCOL USING DOUBLE CENTRIFUGATION METHODS
}

\author{
Hans Kristian Nugraha ${ }^{1}$, Yetti Hernaningsih ${ }^{2}$, Jusak Nugraha ${ }^{2}$ \\ ${ }^{1}$ Medical Doctor Study Program, ${ }^{2}$ Department of Clinical Pathology, \\ Faculty of Medicine, Airlangga University
}

\begin{abstract}
ABSTRAK
Saat ini, terapi dengan Platelet Rich Plasma (PRP) telah banyak digunakan dan terus berkembang untuk berbagai aplikasi klinis. Seiring dengan perkembangannya, ada berbagai pilihan dalam metode memperoleh PRP, baik otomatis atau manual, sedangkan salah satu yang paling dapat diandalkan sesuai dengan literatur adalah metode sentrifugasi ganda. Tujuan dari penelitian ini adalah untuk menghasilkan optimalisasi dari metode sentrifugasi ganda. Penelitian ini menggunakan data eksperimen yang diperoleh oleh para peneliti di Laboratorium Patologi Klinik Rumah Sakit Dr Soetomo, Surabaya. Percobaan pada umumnya dilakukan pada darah yang disimpan diperoleh dari kantong darah dari PMI dengan CPD antikoagulan. Optimalisasi metode sentrifugasi ganda untuk menghasilkan PRP dengan jumlah trombosit yang optimal dapat diperoleh dengan menggunakan tabung berbentuk "I" serta peralatan khusus lainnya yang saat ini tidak tersedia dalam standar laboratorium patologi klinis, dan juga darah segar. Hasilnya peningkatan sebesar 4,11 kali dengan jumlah trombosit 1.152.000. (FMI 2015;51:180-182)
\end{abstract}

Kata kunci: platelet rich plasma, metode sentrifugasi ganda

\begin{abstract}
Currently, therapy with Platelet Rich Plasma (PRP) has been widely used and continues to grow for various clinical applications. Along with its development, there are various options in the method of obtaining PRP, either automatic or manual, while one of the most reliable according to the literature is a double centrifugation method. The purpose of this research is to produce an optimization of the double centrifugation method. This study uses experimental data obtained by researchers at the Clinical Pathology Laboratory of Dr. Soetomo Hospital, Surabaya. Experiments generally were conducted on stored blood obtained from the blood bag from PMI with CPD anticoagulant. Optimization of double centrifugation method to produce PRP with optimum platelet count could be obtained by using an "I"-shaped tube as well as other specialized equipment which are currently not available in standard clinical pathology laboratory, and also fresh blood. The resulting increase amounted to 4.11 times with the platelet count of 1.152 million.(FMI 2015;51:180-182)
\end{abstract}

Keywords: platelet rich plasma, double centrifugation method

Correspondence: Hans Kristian Nugraha, Medical Doctor Program, Faculty of Medicine, Airlangga University, J1. Prof dr. Moestopo 47, Surabaya 60131, Indonesia.

\section{INTRODUCTION}

Currently, therapy with Platelet Rich Plasma (PRP) has been widely used and continues to grow for various clinical applications. Platelet Rich Plasma (PRP) in this case were deemed very potential to be used as a treatment of chronic tendinitis, wound healing, regeneration of cartilage or discs, as well as cardiologists applications. There are various methods used for the manufacture of the PRP, from the sophisticated one that can only be done in a large hospital that has apheresis instrument to the practical one that can be performed directly in the clinic. From a variety of different methods and protocols, in Indonesia has never been any research about what is the most optimal method. There was a need for the Clinical Pathology Laboratory to conduct research and optimization methods in obtaining
PRP. Meanwhile one of the most reliable and relatively simple according to the literature is a double centrifugation method. The purpose of this research is to produce an optimization of the double centrifugation method to produce a protocol that is reliable and have been proven to produce qualified PRP.

\section{MATERIALS AND METHODS}

This study was a laboratory-based experimental research. In this study, samples would be taken from the blood bags from PMI. In this study, PRP was separated from whole blood derived from the bag, manually assessed with standard equipment for laboratory or health care, which includes $10 \mathrm{ml}$ test tube with a scale, 
and a volume of $5 \mathrm{ml}$ syringe with a $21 \mathrm{G}$ needle size 38 $\mathrm{mm}$.

Different treatments performed on a sample derived from donors directly, the use of disposable plastic tubeshaped letter "I" which has a narrow neck with both enlarging end. Other equipment used to complete that special tube includes a long needle $17 \mathrm{G}$ to enter the sample so that it can pass through the narrow neck of the tube and syringe with volume of $1 \mathrm{ml}$ PRP to separate PRP after the second centrifugation. To get as much as $1 \mathrm{ml}$ PRP needed as much as $10 \mathrm{ml}$ sample of blood. For the optimization process of centrifugation and separation step takes 25 repetition, so that the total estimated blood need is $250 \mathrm{ml}$ of blood. This experiment was conducted in the Laboratory of Clinical Pathology, Faculty of Medicine Airlangga University/ Dr. Soetomo General Hospital.

Complete blood tests have been done before the trial began to determine the initial platelet count before being processed. Optimization is done with speed centrifugation speed varied from $160 \mathrm{G}$ to $2000 \mathrm{G}$ and the time varies from 4 minutes to 20 minutes. Blood smear readings have been done after the Centrifugation process without the addition of calcium gluconate. After the primary data obtained through laboratory experi- ments, the data are tabulated and descriptively presented.

\section{RESULTS}

It can be seen that from the research conducted, there are inconsistencies in the correlation between speed and time of centrifugation to the increase in platelet count after the production of PRP using double centrifugation method. The highest increase is given by the sample 022. The centrifugation was done on that samples with a special tube-shaped letter "I" along with other special equipment.

From the overall data derived from a sample from the bag, there was a low initial platelet count results. This may be caused by the absence anticoagulant hoses that connect the donor with the bag on the blood donation process. The absence of anticoagulants caused a large number of platelets undergo activation due to contact with foreign factors. As a result, platelets become used (Consumed) for clot formation along the hose allowing platelet count dropped. Low platelet count can also be found on the bag Platelet Concentrate (PC) that is available on the PMI for the same reasons.

Table 1. Treatment of the samples

\begin{tabular}{|c|c|c|c|c|c|c|c|c|}
\hline \multirow[b]{2}{*}{$\begin{array}{l}\text { Sample } \\
\text { Numb. }\end{array}$} & \multicolumn{2}{|c|}{ 1st Centrifugation } & \multicolumn{2}{|c|}{ 2nd Centrifugation } & \multirow{2}{*}{$\begin{array}{c}\text { Platelet } \\
\text { count } \\
\left(\mathrm{x} 10^{3} / 1\right)\end{array}$} & \multirow[b]{2}{*}{ Increase } & \multirow[b]{2}{*}{ Source } & \multirow[b]{2}{*}{ Note } \\
\hline & $\begin{array}{l}\text { Velocity } \\
\text { (G) }\end{array}$ & $\begin{array}{c}\text { Time } \\
\text { (minutes) }\end{array}$ & $\begin{array}{c}\text { Velocity } \\
(\mathrm{G})\end{array}$ & $\begin{array}{c}\text { Time } \\
\text { (minutes) }\end{array}$ & & & & \\
\hline 001 & - & - & - & - & 92 & & Bag I & \\
\hline 002 & 1200 & 5 & 2000 & 6 & 271 & $2.94 \mathrm{x}$ & Bag I & Standard \\
\hline 003 & - & - & - & - & 87 & & Bag II & \\
\hline 004 & 200 & 15 & 1500 & 15 & 194 & $2.23 \mathrm{x}$ & Bag II & Standard \\
\hline 005 & 300 & 10 & 1500 & 15 & 65 & $0.74 \mathrm{x}$ & Bag II & Standard \\
\hline 006 & 600 & 5 & 1500 & 15 & 106 & $1.21 \mathrm{x}$ & Bag II & Standard \\
\hline 007 & 900 & 5 & 1500 & 15 & 129 & $1.48 \mathrm{x}$ & Bag II & Standard \\
\hline 008 & 1200 & 5 & 1500 & 15 & 33 & $0.37 \mathrm{x}$ & Bag II & Standard \\
\hline 009 & 1500 & 5 & 1500 & 15 & 41 & $0.47 \mathrm{x}$ & Bag II & Standard \\
\hline 010 & 200 & 15 & 2000 & 6 & 90 & $1.03 \mathrm{x}$ & Bag II & Standard \\
\hline 011 & 300 & 10 & 2000 & 6 & 47 & $0.54 \mathrm{x}$ & Bag II & Standard \\
\hline 012 & 600 & 5 & 2000 & 6 & 23 & $0.26 \mathrm{x}$ & Bag II & Standard \\
\hline 013 & 900 & 5 & 2000 & 6 & 31 & $0.35 \mathrm{x}$ & Bag II & Standard \\
\hline 014 & 1200 & 5 & 2000 & 6 & 37 & $0.43 \mathrm{x}$ & Bag II & Standard \\
\hline 015 & 1500 & 5 & 2000 & 6 & 33 & $0.38 \mathrm{x}$ & Bag II & Standard \\
\hline 016 & - & - & - & - & 170 & & Mixed & \\
\hline 017 & 200 & 15 & 1500 & 15 & 62 & $0.36 \mathrm{x}$ & Mixed & Standard \\
\hline 018 & - & - & - & - & 104 & & Bag II & \\
\hline 019 & 200 & 15 & 600 & 15 & 109 & $1.04 \mathrm{x}$ & Bag II & Standard \\
\hline 020 & $200+600$ & $15+15$ & 1500 & 10 & 29 & $0.28 \mathrm{x}$ & Bag II & Standard \\
\hline 021 & - & - & - & - & 280 & & Donor & \\
\hline 022 & 1300 & 5 & 2300 & 7 & 1152 & $4.11 \mathrm{x}$ & Donor & Tube-Shaped "I" \\
\hline 023 & $900+1300$ & 5 & 2300 & 7 & 37 & $0.36 \mathrm{x}$ & Bag II & Standard \\
\hline $024 a$ & 1300 & 5 & - & - & 72 & $0.69 \mathrm{x}$ & Bag II & Standard \\
\hline $024 \mathrm{~b}$ & 1300 & 5 & 2300 & 7 & 22 & $0.21 \mathrm{x}$ & Bag II & Standard \\
\hline
\end{tabular}




\section{DISCUSSION}

Platelet count results after double centrifugation process for the blood that is coming from the bag varies, but the results showed $68.42 \%$ significant decrease in platelet, even reaching the lowest value of 0.21 times of the initial platelet count rate. Meanwhile the remaining 6 samples showed varying improvement in the absence of a clear correlation between speed and time of centrifugation to the increase of platelet count. Thus, the average platelet count results after the double centrifugation method was 0.81 times that of the results of platelet count before the process.

This contrasts with the results of the study by $\mathrm{CH}$ Jo and his colleagues from the department of orthopedic surgery, Seoul National University Hospital Boramae, which states that the results of the platelet count in double centrifugation method will reaching optimum with the first centrifugation speeds of $900 \mathrm{G}$ for 5 minutes and the speed of the second centrifugation for 15 minutes at $1500 \mathrm{G}$ (CH Jo et al, 2011).

Such is possible because in this study PRP of the second centrifugation results are not resuspended, just left on the tube as many as $10 \mathrm{~mm}$ before platelets counting. So lacking in accordance with the treatment used by Gonshor A that is already formed PRP is resuspended before with erythrocytes and buffy coat that were left to form non-pure PRP (Gonshor 2002). This resuspension being important because of platelets in the buffy coat will free so increasing the number of platelets in PRP. In addition, it is possible that the use of already saved blood affects the quality of platelets giving unsatisfactory results.
The results of platelet count on the samples using a special tube-shaped "I" is derived from the donor directly with the addition of ACD anticoagulant in the ratio 1:9 showed results in line with expectations, where the number of platelet count reached more than 1 million $/ \mathrm{mL}$ with an increase more than 4 times. However, considering the high cost of experimentation, in this study only used one sample just for this special treatment.

\section{CONCLUSION}

The quality of the resulting PRP is not overly dependent on the speed and time of centrifugation separation of PRP. Making manually PRP is determined by technical factors separating the tools and expertise. Optimal number of PRP can be achieved by using special equipment with tube and centrifugation speed first of $1300 \mathrm{G}$ for 5 minutes followed by a second centrifugation at $2300 \mathrm{G}$ speed for 7 minutes. To date, high quality PRP can be more easily achieved with the use of specialized tools PRP-making that has been tested and clarified to process the blood directly.

\section{REFERENCES}

Gonshor, A. Technique for producing platelet-rich plasma and platelet concentrate:Background and process. Int. J. Periodontics Restorative Dent. 22:547, 2002.

Jo CH, Roh YH, Kim JE, Shin S, Yoon KS, Noh JH. Optimizing Platelet-Rich Plasma Gel Formation by Varying Time and Gravitational Forces During Centrifugation. J Oral Implantol. 2011 Apr 11. 